\title{
DIETER SIMONS†
}

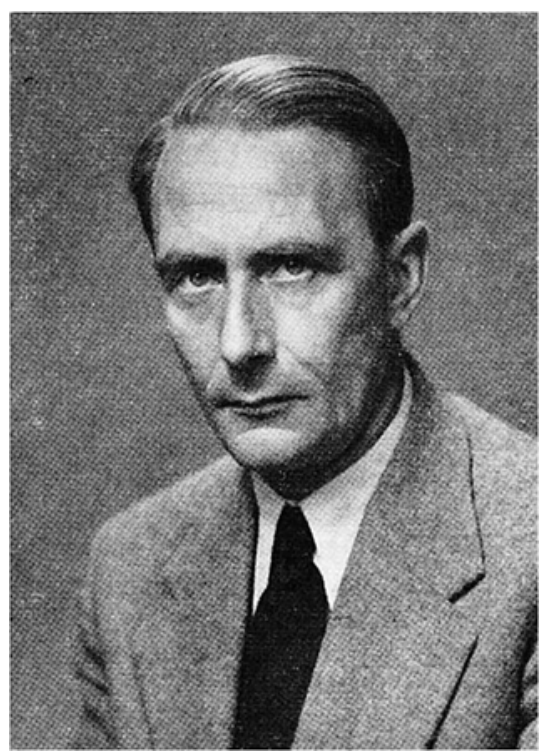

In tiefer Trauer beehre ich mich. davon Kenntnis zu geben, daß der Leiter der Sektion "Mechanisierung im Kartoffelbau" der Europäischen Gesellschaft für Kartoffelforschung.

Herr Professor Dr.-Ing. Dieter Simons.

Direktor des Instituts für Landmaschinenforschung der

Forschungsanstalt für Landwirtschaft Braunschweig-Völkenrode.

am 1. Mai 1960 im Alter von 48 Jahren auf einer Dienstreise einem Herzschlag erlegen ist.

Herr Professor Simons war mit seinem großen Wissen und seiner echten Bescheidenheit allen Fachwissenschaftlern und Praktikern Vorbild. Die Europäische Gesellschaft für Kartoffelforschung schuldet ihm in Anerkennung seiner Tätigkeit für die geleistete Aufbauarbeit tiefen Dank.

Sein früher und unerwarteter Tod hinterläßt in den Reihen der Europäischen Gesellschaft für Kartoffelforschung eine tiefe Lücke, die sich nur schwer schließen lassen wird.

Sein Andenken wird stets in Ehren gehalten werden.

Für Vorstand und Mitglieder der EAPR

Der Präsident

Prolessor Dr. O. FischNich 